\title{
Levels of Heavy Metals in some Commercially available Rice on the Liberian Market
}

\section{G. L. Gomah ${ }^{1 *}$, R.B. Voegborlo', R. S. Ngumbu²}

${ }^{1}$ Department of Chemistry, College of Science, Kwame Nkrumah University of Science \& Technology, Kumasi, Ghana

${ }^{2}$ Department of Chemistry, T.J.R. Faulkner College of Science; University of Liberia, Monrovia, Liberia

\begin{abstract}
Human activities such as agriculture, mining, urbanization and waste disposal can lead to heavy metals contamination of food crops, including rice meant for human consumption. In an effort to ensure quality and safe food consumption, this study determined the levels of toxic heavy metals, Arsenic (As), Cadmium (Cd), Chromium (Cr), Lead $(\mathrm{Pb})$, Mercury $(\mathrm{Hg})$ and Nickel $(\mathrm{Ni})$ in rice brands widely consumed in Liberia. Hg was determined by AAS technique using a Lumex RA-915M portable Zeeman Automatic Mercury Analyzer. As, Cd, $\mathrm{Cr}, \mathrm{Pb}$ and Ni were determined by ICP-MS technique using an Agilent 7900 ICP-MS. The levels of As, Cd, Cr, $\mathrm{Pb}, \mathrm{Hg}$ and $\mathrm{Ni}$ concentrations ranged from 1.1 to $18.1,4.8$ to $117.9,5.0$ to $424.5,1.1$ to $37.1,1.1$ to 9.4 and 15.1 to $655.2 \mu \mathrm{g} / \mathrm{kg}$ respectively. The study revealed no significant statistical variability in the metal concentrations between the locally cultivated and imported rice, except for As ( $\mathrm{P}=0.002)$. The levels of $\mathrm{As}, \mathrm{Cd}, \mathrm{Pb}$ and $\mathrm{Hg}$ in all brands were below the World Health Organization/Food and Agricultural Organization guideline values. $\mathrm{Cr}$ and Ni levels were also below the Chinese Guidelines for all rice brands analyzed. The results imply that although the rice brands analyzed contain low heavy metal concentrations, the levels are unlikely to cause adverse health effects to the consuming populace.
\end{abstract}

Keywords : Monrovia, Rice, Heavy Metals

\section{INTRODUCTION}

Food safety remains one of the foremost problems faced by the world today. Many of our food items may be loaded with contaminants such as pesticide residues, fertilizers components and heavy metals [1]. Heavy metals contamination of food has become a major concern in the world due to their toxicological effects on human [2]. These metals naturally exist in soil, air, and water and are rapidly dispersed by human activities such as urbanization, waste disposal, agricultural chemicalization, mining, among others. Heavy metals such as Lead, Arsenic Cadmium and Mercury are considered non-essential because they do not have any significance in the biochemical processes that take place in human bodies. On the other hand, some elements such as Chromium and Nickel are considered essential but become toxic at comparatively low concentration [3].

Excessive intakes of dietary heavy metals have been shown to cause serious health problems. For examples, the occurrence of the 1955 Itai Itai disease disaster in Japan resulted from the consumption of rice containing high levels of cadmium [4].

In Liberia, rice is the major staple food for both urban and rural citizens though it is commercially produced 
on a small scale. Therefore, many of the rice consumed in Liberia are imported from mostly Asian countries [5,6]. Early studies have revealed the presence of notable levels of heavy metals in rice grains from these countries [7-9]. However, the level of contaminants in the imported brands of rice on the Liberian national market is not reported.

Furthermore, locally cultivated rice is preferred by some members of the population. Aside the use of agrochemicals and other processes leading to rice production, the location of rice farms may also contaminate the product. Some rice species are grown on farms located near mining areas or wastes disposal sites. After a heavy downpour, effluents from these mining areas and waste deposits percolate into the soil and also into bodies of waters, which may be used by rice producers for irrigation. Considering the toxic nature of heavy metals, this study aimed at assessing their levels of contamination in the widely consumed rice sold on the Liberian markets.

\section{MATERIAL AND METHODS}

\section{Sampling}

Sixty-one rice samples of imported and locally cultivated brands were purchased on different occasions from local markets in and around the capital city of Liberia. Samples were collected in freshly purchased and labelled clear clean polyethylene zip lock sampling bags, after which they were packed in solid polyethylene food box, sealed and transported from Liberia to the KNUST Chemistry Department, Kumasi, Ghana for analysis.

\section{Reagents}

All stock standard solutions chemicals and reagents used in this study were of analytical grade unless otherwise stated. All dilutions were made with deionized water. Reagents used in this study include Sulphuric acid $\left(\mathrm{H}_{2} \mathrm{SO}_{4}\right)$, Perchloric acid $\left(\mathrm{HClO}_{4}\right)$,
Potassium permanganate $\left(\mathrm{KMnO}_{4}\right)$, and Nitric acid $\left(\mathrm{HNO}_{3}\right)$. The $98 \% \mathrm{H}_{2} \mathrm{SO}_{4}, 70 \% \mathrm{HClO}_{4}$ and $65 \%$ $\mathrm{HNO}_{3}$ concentration acids used were obtained from Merck, Darmstadt (Germany). Various concentrated stock standard solutions for each metal were products of Agilent Technology, California (USA). Potassium permanganate $\left(\mathrm{KMnO}_{4}\right)$ was from Breckland Scientific, Stafford (UK).

\section{Chemical Analysis \\ Sample Digestion}

Samples were cleaned thoroughly, homogenized and digested by an open tube digestion procedure according to Voegborlo and Akagi [10]. The accuracy of the method has been proven by Certified Reference Materials, such as IAEA-085, IAEA-142 and IAEA-407. In the digestion method, 1 gram of homogenized sample each was weighed in a 50 millimeter graduated Pyrex digestion tube. Added to the tube were 1 milliliter of deionized water, 4 millimeters of 1:1 concentrated Nitric-Perchloric acids $\left(\mathrm{HNO}_{3}-\mathrm{HClO}_{4}\right)$ and 5 millimeters of concentrated Sulphuric acid $\left(\mathrm{H}_{2} \mathrm{SO}_{4}\right)$. The mixture was swirled for about 1 minute and the tube with contents were then inserted into an aluminum heating block and placed on an electric Aluminum Hotplate set at $200^{\circ} \mathrm{C}$ until clear transparent solutions were obtained. The final solutions were shaken thoroughly and filtered through 42 grade Whatman filter papers into top capped polyethylene bottles and kept in fridge until analysis. Digestion blanks were prepared during the digestion process.

\section{Determination of Metals}

The concentrations of $\mathrm{Hg}$ in the samples were determined by Atomic Absorption Spectroscopy technique using a RA-915M (Lumex Instruments, Canada) portable Zeeman Automatic Mercury Analyzer and the concentrations of $\mathrm{As}, \mathrm{Cd}, \mathrm{Cr}, \mathrm{Pb}$ and $\mathrm{Ni}$ were determined by an Inductively Coupled Plasma Mass Spectrometry (ICP-MS) technique using an Agilent 7900 (Agilent Technology, USA) 
Inductively Couple Plasma Mass Spectrophotometer. Before the determination of the analytes, the instruments were calibrated to determine their response to calibration standards of known concentrations. The stock solutions of the analytes were used to prepare calibration standards with varying concentrations and their signals were measured to obtain calibration curves, which were used to determine the concentration of the analytes in the digests.

\section{Quality Assurance}

A Standard Certified Reference Material (IAEA-359) obtained from the analytical quality control services unit of the International Atomic Energy Agency (Vienna, Austria) was used to ascertain the accuracy of the digestion and analytical measurement processes.

\section{Statistical Analysis}

Microsoft Excel (v2016) and IBM-SPSS (v23.0) tools were employed for statistical analysis. All P-Values $\leq$ 0.05 were considered significant.

\section{RESULTS}

A total of 61 rice samples collected from local markets in Liberia were analyzed for the levels of Arsenic (As), Cadmium (Cd), Chromium (Cr), Mercury $(\mathrm{Hg})$, Lead $(\mathrm{Pb})$ and Nickel (Ni). The accuracy of the analytical procedure used in this study was validated by a Certified Reference Material (IAEA-359). Result of the CRM is summarized in Table 1. Recovery percentage were in the range of 90.00 to $107.2 \%$, indicating accuracy of the analytical techniques.

The results for the tested metals in the analyzed samples are presented in figures 1 to 6 . The result indicates that the selected metals were all present in all the tested rice samples, and a wide range of contamination values was observed. The levels of contamination ranked in the order of $\mathrm{Ni}>\mathrm{Cr}>\mathrm{Cd}>$ $\mathrm{Pb}>\mathrm{Hg}>$ As. The concentrations of the metals ranged from 1.1 to $18.1 \mu \mathrm{g} / \mathrm{kg}$ for As, 4.8 to 117.9 $\mu \mathrm{g} / \mathrm{kg}$ for $\mathrm{Cd}, 5.0$ to $424.5 \mu \mathrm{g} / \mathrm{kg}$ for $\mathrm{Cr}, 1.1$ to 37.1 $\mu \mathrm{g} / \mathrm{kg}$ for $\mathrm{Pb}, 1.1$ to $9.4 \mu \mathrm{g} / \mathrm{kg}$ for $\mathrm{Hg}$ and 15.1 to 655.2 $\mu \mathrm{g} / \mathrm{kg}$ for $\mathrm{Ni}$. Student T-test performed at $95 \%$ confidence interval produced P-Values of 0.002 for As, 0.195 for Cd, 0.96 for $\mathrm{Cr}, 0.113$ for $\mathrm{Pb}, 0.254$ for $\mathrm{Hg}$ and 0.081 for $\mathrm{Ni}$. This showed no significant statistical difference in the level of metal concentrations between the imported and the locally cultivated rice samples, except for As. The difference in As concentration could be attributed to regional difference in the cultivation of the rice samples. Zavala and Duxbury [11] reported that geographic location is the key factor to arsenic variability in rice grains.

Table 1 : Results $(\mu \mathrm{g} / \mathrm{kg})$ of CRM (IAEA-359) showing certified values, measured values and percent recoveries.

\begin{tabular}{|l|l|l|l|l|}
\hline Element & $\begin{array}{l}\text { Certified } \\
\text { Value }\end{array}$ & $\mathrm{n}$ & $\begin{array}{l}\text { Mean } \\
\text { Value }\end{array}$ & $\begin{array}{l}\% \\
\text { Recovery }\end{array}$ \\
\hline $\mathrm{As}$ & 100.0 & 3 & 90.00 & 90.00 \\
\hline $\mathrm{Cd}$ & 120.0 & 3 & 110.0 & 91.67 \\
\hline $\mathrm{Cr}$ & 1300 & 3 & 1283 & 98.69 \\
\hline $\mathrm{Hg}$ & 13.00 & 3 & 13.94 & 107.2 \\
\hline $\mathrm{Ni}$ & 1050 & 3 & 1067 & 101.6 \\
\hline
\end{tabular}

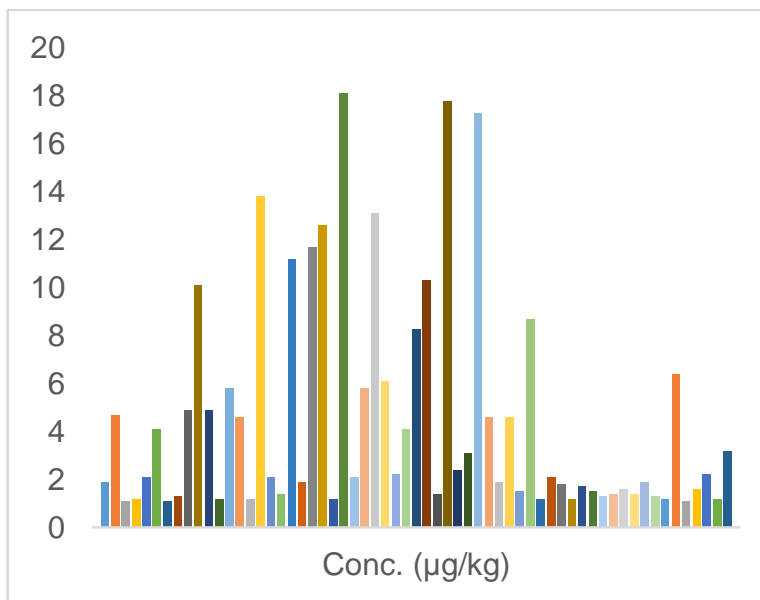


Figure 1 : Concentration $(\mu \mathrm{g} / \mathrm{kg})$ of As in the rice samples

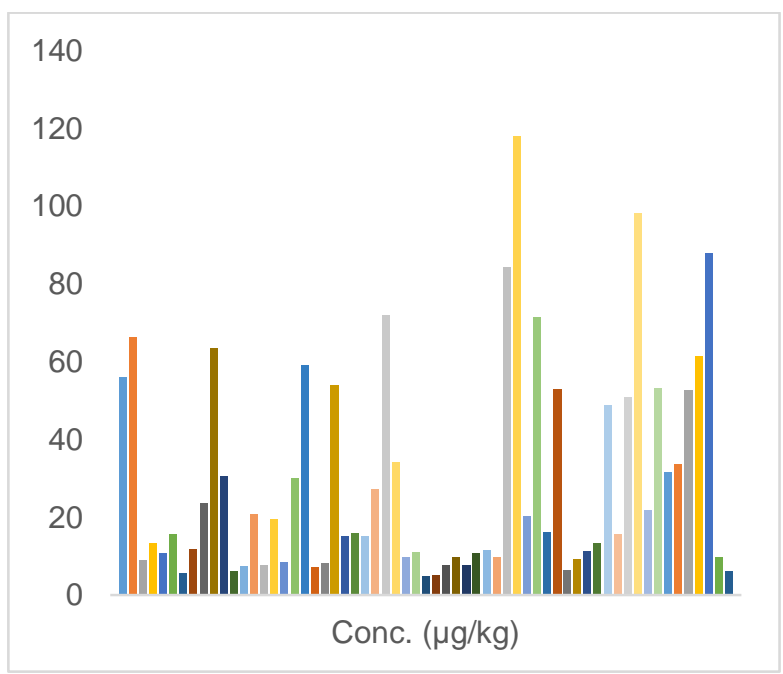

Figure 2 : Concentration $(\mu \mathrm{g} / \mathrm{kg})$ of $\mathrm{Cd}$ in the rice samples

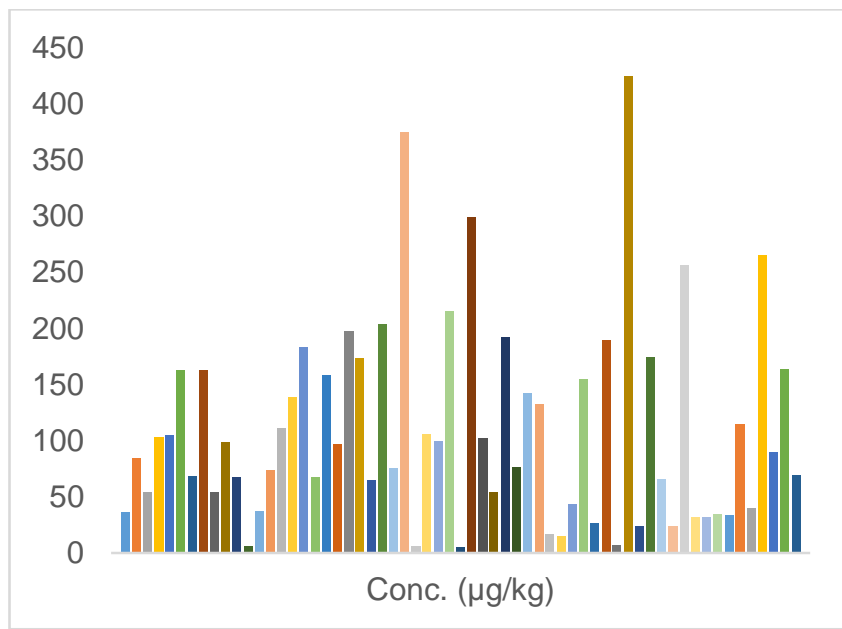

Figure 3 : Concentration $(\mu \mathrm{g} / \mathrm{kg})$ of $\mathrm{Cr}$ in the rice samples

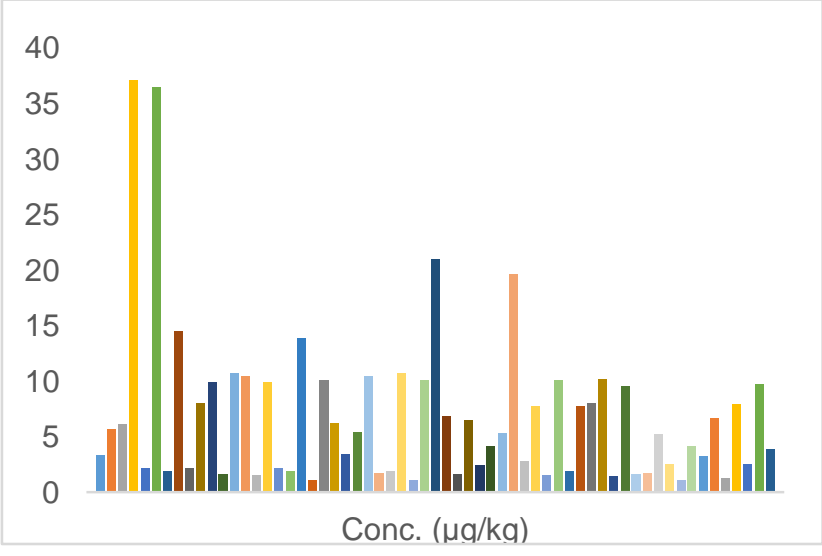

Figure 4 : Concentration $(\mu \mathrm{g} / \mathrm{kg})$ of $\mathrm{Pb}$ in the rice samples

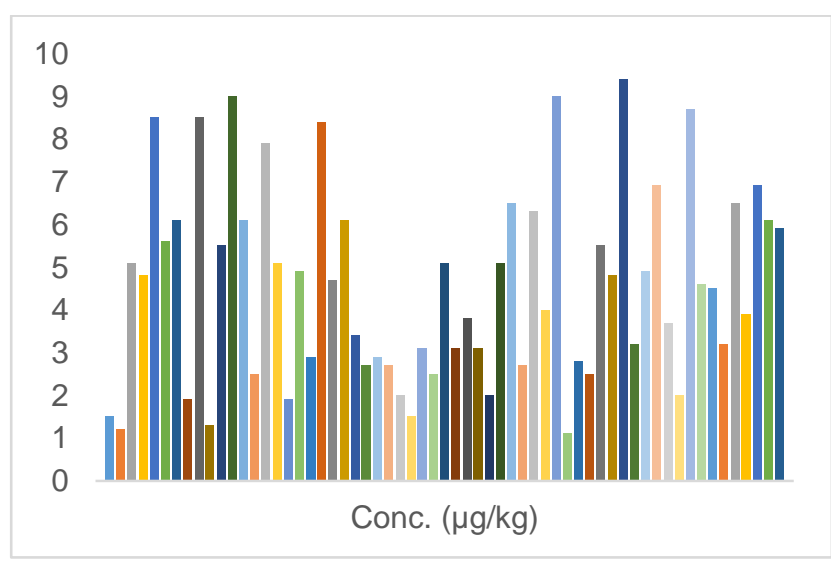

Figure 5 : Concentration $(\mu \mathrm{g} / \mathrm{kg})$ of $\mathrm{Hg}$ in the rice samples

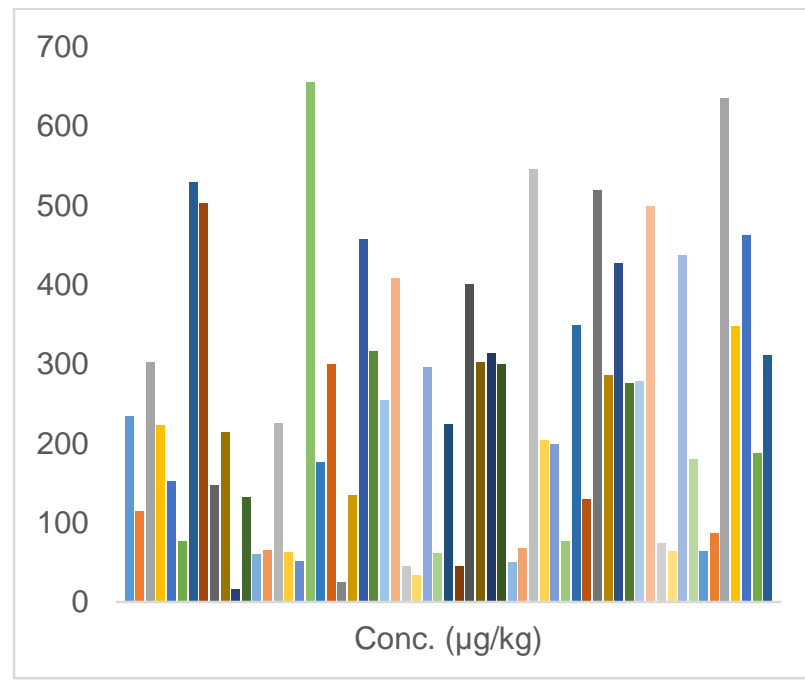

Figure 6 : Concentration $(\mu \mathrm{g} / \mathrm{kg})$ of $\mathrm{Ni}$ in the rice samples

\section{DISCUSSION}

Rice is the second most cultivated cereal and the third most worldwide produced crop, that provides about $30 \%$ dietary energy and $20 \%$ dietary proteins to consumers [12]. It has been implicated as the major source of dietary exposure to Heavy metals, such as $\mathrm{As}, \mathrm{Cd}, \mathrm{Cr}, \mathrm{Pb}, \mathrm{Hg}$ and $\mathrm{Ni}$ [13].

The level of As concentrations documented in this study were low when compared to the $200 \mu \mathrm{g} / \mathrm{kg}$ 
threshold limit recommended by the Codex Alimentary Commission [14]. The highest concentration of As in the samples was 181.9 folds lower than the Codex Standard. This showed low As contamination of the rice products. According to Meharg [15], rice cultivated on dry land or under moderate sunny conditions may contain low concentration of As compared to rice cultivated in region with continues flood. The low concentration of As recorded for the tested samples may be influenced by their cultivation conditions. Though this study recorded low levels of As in rice, others studies have reported high levels of As concentration in rice samples analyzed in China and India respectively $[16,17]$.

The presence of Cadmium in rice grains is due to its similarities to essential elements such as Calcium and Magnesium. Even in minute concentration, and under low conditions of these elements $(\mathrm{Ca}$ and $\mathrm{Mg})$, it is passively or actively absorbed by the root system and translocated to other parts of the plants [18]. However, it uptake can be inhibited by the presence of silicon ( $\mathrm{Si}$ ) in the plant's cell wall. Therefore, in a cadmium contaminated soil, silicate fertilizers are usually applied during rice cultivation. The application of this fertilizer inhibits the uptake of the element, and therefore account for it low level in rice grain. Cadmium concentrations reported in all the rice samples analyzed were less than the $400 \mu \mathrm{g} / \mathrm{kg}$ threshold limit recommended by the Codex Alimentary Commission. The values were also less than the $200 \mu \mathrm{g} / \mathrm{kg}$ limit recommended by the European Commission [19]. This indicates low contamination of the tested rice samples by $\mathrm{Cd}$. The levels also indicated that the samples might have been cultivated on soils rich in Calcium or Magnesium, or silicate fertilizers might have been used during the cultivation periods. Cd concentration reported for rice consumed in Sindh, Pakistan, were in agreement with the values recorded in this study [20].
The concentrations of $\mathrm{Pb}$ in all the analyzed rice samples were less than $50 \mu \mathrm{g} / \mathrm{kg}$, which is less than the $200 \mu \mathrm{g} / \mathrm{kg}$ threshold limit recommended by the European Commission and adopted by the Codex Alimentary Commission. The level of $\mathrm{Hg}$ concentrations found in all the rice tested were less than $10 \mu \mathrm{g} / \mathrm{kg}$, which is significantly below the 200 $\mu \mathrm{g} / \mathrm{kg}$ threshold limit set by the European Commission, an indication of low contamination of the tested products by the metals. Soil $\mathrm{pH}$ and redox potential are the basic factors responsible for the presence of $\mathrm{Pb}$ and $\mathrm{Hg}$ in rice grains. Under low $\mathrm{pH}$ and redox potential, these metals are bioavailable in high concentrations to the plant [21]. However, their accumulation in the grain is not positively correlated to the amount of the metals absorbed by the plant [22]. Hg levels obtained in this study showed little disparities when compared to other studies published in literature [23-25]. For $\mathrm{Pb}$, the range reported by Huang et al. [26] was in agreement with this study but below the range documented in these articles $[27,28]$.

Nickel and Chromium had the highest concentrations in the tested samples. This can be traceable to their essentiality to many plants and animals. For example, in most plants, including rice, nickel served as urease cofactor, aiding in the production of plants nitrogen or ammonium ions [29], while chromium is needed in minute concentration for growth stimulation [30]. Under normal soil condition, rice is known to absorb and utilize minute concentrations of these metals. Their uptake process is similar to the uptake of iron. Therefore, in excess amount, they suppressed the uptake of iron, leading to the absorption of more soluble and exchangeable amounts of the elements by the plant. However, their tolerance is also enhanced by the application of exogenous silicon fertilizer [31]. Nickel and Chromium levels in this study were similar to other studies from Ethiopia, India and Iran $[9,32,33]$. The European Commission and the Codex 
Alimentary Commission had not established a threshold for nickel and chromium in rice, but the Food Safety Authorities of the Peoples' Republic of China recognized $1000 \mu \mathrm{g} / \mathrm{kg}$ and $1500 \mu \mathrm{g} / \mathrm{kg}$ as a threshold for the metals in grains and other cereals respectively [34]. Though the two metals recorded the highest values in the hierarchy order of contamination of the samples, their values were less than their respective threshold limits recommended by the Food Safety Authorities of the Peoples' Republic of China. The highest concentrations of $\mathrm{Cr}$ and $\mathrm{Ni}$ concentrations in all the analyzed rice samples were about $58 \%$ and $56 \%$ lesser than their respective permissible limits. This showed very low dietary contamination of the tested rice products by the metals.

\section{CONCLUSION}

The study assessed the levels of heavy metals (As, Cd, $\mathrm{Cr}, \mathrm{Pb}, \mathrm{Hg}$ and $\mathrm{Ni}$ ) in commercially available rice on the local markets in Liberia. The selected heavy metals were all present in all the rice samples analyzed. There was no significant statistical variability in the level of metal concentrations between the imported and the locally cultivated rice samples, except for As. The concentrations of As, Cd, $\mathrm{Pb}$ and $\mathrm{Hg}$ in the studied samples were generally below the Codex and European Commission threshold limits. $\mathrm{Cr}$ and $\mathrm{Ni}$ were also below the Chinese permissible limit. This showed low contamination of the selected rice brands by the metals, and therefore safe for human consumption. However, high level of heavy metals contamination is possible. Therefore, the level of heavy metals in these rice brands must be regularly monitored to ensure the safety of consumers.

\section{REFERENCES}

[1]. Grunert KG. Food quality and safety: consumer perception and demand. Eur Rev Agric Econ. 2005;32(3):369-91.

[2]. Kalamdhad AS, Singh J. Effects of Heavy Metals on Soil, Plants, Human Health and Aquatic Life. Int $\mathrm{J}$ Res Chem Environ. 2011;1(2):15-21.

[3]. Sharma RK, Agrawal M. Biological effects of heavy metals: An overview. J Environ Biol. 2014;26(2):301-13.

[4]. Yoshida F, Hata A, Tonegawa H. I tai-Itai disease and the countermeasures against cadmium pollution by the Kamioka mine. Environ Econ Policy Stud. 2009;2(3):215-29.

[5]. Seck PA, Tollens E, Wopereis MCS, Diagne A, Bamba I. Rising trends and variability of rice prices: Threats and opportunities for subSaharan Africa. Food Policy. 2010;35(5):40311.

[6]. Balasubramanian V, Sie M, Hijmans RJ, Otsuka K. Increasing Rice Production in Sub-Saharan Africa: Challenges and Opportunities. Adv Agron. 2007;94(6):1-79.

[7]. Zhuang P, Mcbride MB, Xia H, Li N, Li Z. Health risk from heavy metals via consumption of food crops in the vicinity of Dabaoshan mine, South China. Sci Total Environ. 2008;407(5):1551-61.

[8]. Payus C, Farhana A, Talip A. Assessment of heavy metals accumulation in paddy rice ( Oryza sativa ). African J Agric Res. 2014;9(41):3082-90.

[9]. Naseri M, Vazirzadeh A, Kazemi R, Zaheri F. Concentration of Some Heavy Metals in Rice Types Available in Shiraz Market and Human Health Risk Assessment. Food Chem. 2014;9:1-22.

[10]. Voegborlo RB, Akagi H. Determination of mercury in fish by cold vapour atomic 
absorption spectrometry using an automatic mercury analyzer. Food Chem. 2007;100(2):853-8.

[11]. Zavala YJ, Duxbury JM. Arsenic in Rice: Estimating Normal Levels of Total Arsenic in Rice Grain. Environ Sci Technol. 2008 May;42(10):3856-60.

[12]. FAO. Rice international commodity profile. Vol. 2, Food and Agriculture Organization. Rome, Italy; 2008.

[13]. Satpathy D, Reddy MV, Dhal SP, Satpathy D, Reddy MV, Dhal SP. Risk Assessment of Heavy Metals Contamination in Paddy Soil, Plants, and Grains ( Oryza sativa L.) at the East Coast of India. Biomed Res Int. 2014;10:1-11.

[14]. CODEX. General Standard for Contaminants and toxins in food and feed (Codex Stan 1931995). Codex Alimentarius Commission of the Food and Agriculture Organization/ World Health Organization. Rome, Italy; 2015. p. 759.

[15]. Meharg AA. Arsenic in rice - Understanding a new disaster for South-East Asia. Trends Plant Sci. 2004;9(9):415-7.

[16]. Song D, Zhuang D, Jiang D, Fu J, Wang Q. Integrated health risk assessment of heavy metals in Suxian county, South China. Int J Environ Res Public Health. 2015;12(7):710017.

[17]. Giri S, Singh AK. Human health risk assessment due to dietary intake of heavy metals through rice in the mining areas of Singhbhum Copper Belt, India. Environ Sci Pollut Res. 2017;24(17):149-61.

[18]. Ma J, Cai H, He C, Zhang W, Wang L. A hemicellulose-bound form of silicon inhibits cadmium ion uptake in rice (Oryza sativa) cells. New Phytol. 2015;206(3):1063-74.

[19]. EC. Commission Regulation (EC) No 1881/2006 of 19 December 2006 setting maximum levels for certain contaminants in foodstuffs. Off J Eur Communitites.
2006;L364(1881):5-24.

[20]. Jalbani N, Aftab AK, Bhutto S, Ahmed F, Mahroze AK. Evaluation of toxic elements in rice (Oryza sativa) commercially available in Pakistan; multivariate study. Int Food Res J. 2014;21(1):255-61.

[21]. Zeng F, Mao Y, Cheng W, Wu F, Zhang G. Genotypic and environmental variation in chromium, cadmium and lead concentrations in rice. Environ Pollut. 2008;153(2):309-14.

[22]. Liu J, Li K, Xu J, Zhang Z, Ma T, Lu X, et al. Lead toxicity, uptake, and translocation in different rice cultivars. Plant Sci. 2003;165(4):793-802.

[23]. Da Silva MJ, Paim APS, Pimentel MF, Cervera ML, de la Guardia M. Determination of mercury in rice by cold vapor atomic fluorescence spectrometry after microwaveassisted digestion. Anal Chim Acta. 2010 May 14;667(1-2):43-8.

[24]. Da Silva DG, Portugal LA, Serra AM, Ferreira SLC, Cerdà V. Determination of mercury in rice by MSFIA and cold vapour atomic fluorescence spectrometry. Food Chem. 2013 Apr 15;137(1-4):159-63.

[25]. Cao H, Chen J, Zhang J, Zhang H, Qiao L, Men Y. Heavy metals in rice and garden vegetables and their potential health risks to inhabitants in the vicinity of an industrial zone in Jiangsu, China. J Environ Sci. 2010;22(11):1792-9.

[26]. Huang Z, Pan XD, Wu PG, Han JL, Chen Q. Health Risk Assessment of Heavy Metals in Rice to the Population in Zhejiang, China. PLoS One. 2013;8(9):1-6.

[27]. Rahman MM, Owens G, Naidu R. Arsenic levels in rice grain and assessment of daily dietary intake of arsenic from rice in arseniccontaminated regions of Bangladesh Implications to groundwater irrigation. Environ Geochem Health. 2009;31:179-87.

[28]. Otitoju O, Iyeghe L, Onwurah I. 
Quantification of Heavy Metals in Some Locally Produced Rice ( Oryza Sativa ) from the Northern Region of Nigeria . J Environ Heal Sci. 2014;4(1):67-71.

[29]. Liu G, Simonne EH, Li Y. Nickel Nutrition in Plants- Functions of Nickel in Plants and Symptoms of Nickel Deficiency [Internet]. University of Florida IFAS Extension. Gainesville, Florida; 2017. p. 2-7. Available from: http://edis.ifas.ufl.edu. Cited: Dec 10, 2017.

[30]. Tripathi DK, Singh VP, Kumar D, Chauhan DK. Impact of exogenous silicon addition on chromium uptake, growth, mineral elements, oxidative stress, antioxidant capacity, and leaf and root structures in rice seedlings exposed to hexavalent chromium. Acta Physiol Plant. 2012;34(1):279-89.

[31]. Bhattacharyya P, Chakraborty A, Chakrabarti K, Tripathy S, Powell MA. Chromium uptake by rice and accumulation in soil amended with municipal solid waste compost. Chemosphere. 2005;60(10):1481-6.

[32]. Belayneh T, Atnafu Z, Madhusudhan A. Determination of the levels of essential and non-essential metals in rice and soil samples. Int J Mod Chem Appl Sci. 2015;2(1):65-72.

[33]. Yousefi N, Meserghani M, Bahrami H, Mahvi AH. Assessment of Human Health Risk for Heavy Metals in Imported Rice and its Daily Intake in Iran. Res J Environ Toxicol. 2016;10(1):75-81.

[34]. Bugang W, Woolsey M. National Food Safety Standard-Maximum Levels of Contaminants in Foods (GB 2762-2010). Ministry of Health of China. Washington D.C: Global Agricultural Information Network, USDA; 2010. p. 2-7. 